\title{
Ant book deepens divide over web publishing
}

Rex Dalton, San Diego

A disagreement about ants has highlighted increasing conflict between biologists and book publishers over the release of scientific monographs in print and online.

Brian Fisher, an entomologist at the California Academy of Sciences in San Francisco, is pressing for permission to publish data about ant species on the Internet. Under the terms of a book deal he signed last August with Harvard University Press, he cannot put material from his forthcoming monograph online for at least four years after it is printed.

The argument is just one example of the tension that is pervading several fields of systematic biology, researchers say. Many systematists want to publish their data and images on the web at the same time as they publish their monographs - hefty books that can document years of research. But publishers fear that simultaneous web publishing will reduce sales of the high-cost monographs.

"We are on the cusp of a renaissance in systematics," says biologist Edward Wilson of Harvard University in Cambridge, Massachusetts. "But we are in a transition period of one form of publishing to another."

Fisher's deal with the Harvard press involves a monograph on the ants of Madagascar, where the isolated and diverse ecosystem is of special interest to systematic biologists. Fisher hopes that the book will be published next year.

But Fisher also recently helped to launch AntWeb (www.antweb.org), a website that includes photographs of ants from Madagascar and California (see Nature 424, 242; 2003). Harvard press officials are resisting his attempts to publish much of his data online before the monograph is published, worried that it will dent the book's future sales.

"I don't think the web release of material will hurt book sales; it will actually increase them," Fisher says. Other researchers cite the US National Academies Press as an example of a publisher whose free online publication of its studies boosts its print sales. Correspondence shows that Harvard press disagrees, and is concerned about its ability to recover its costs in producing the monograph if AntWeb publishes much of its contents.Harvard press officials declined to comment on the dispute.

"These are difficult questions," says Lynne Withey, director of the University of California Press. "People disagree about whether the web hurts or helps." Officials at the California publisher are studying 30 of their social-science and humanities books to determine the impact of online publishing on a traditional monograph.

The recent publication by Harvard University Press of Wilson's book Pheidole in

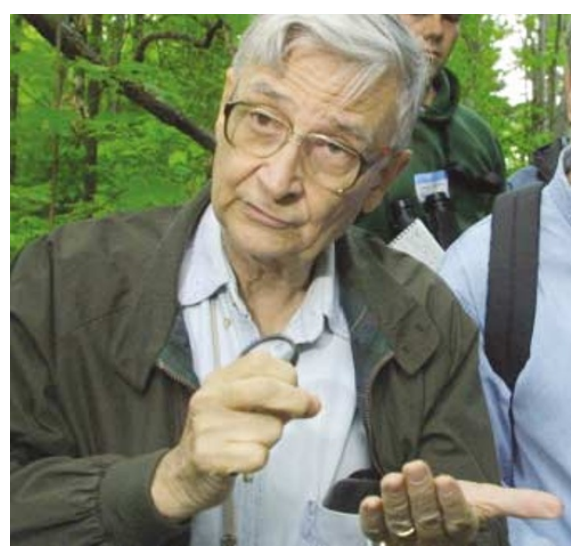

Edward Wilson believes that the age of the printed monograph could be at an end.

the New World: A Dominant, Hyperdiverse Ant Genus also brought criticism from some quarters about the lack of immediate free web access to its contents (see Nature 424, $727 ; 2003)$. He says that the publisher is now putting the book online.

Wilson thinks that the best solution is for book publishers to put monographs online 6-12 months after print publication. He says that his latest book might be one of the last of its kind - "one of the last of the great sailing ships", as he puts it, adding: "We need to work out some arrangement with publishers."

\section{India launches plan for mission to map the Moon}

\section{K. S. Jayaraman, New Delhi}

India has announced that it will send an unmanned satellite to the Moon by 2008 - but observers are divided over the wisdom of the US\$100-million project.

The mission, called Chandrayan-1, was first mooted by the Indian Space Research Organisation (ISRO) in 1999. It will put a 525-kilogram satellite in polar orbit 100

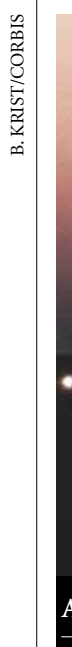

kilometres above the Moon's surface.

Prime Minister Atal Bihari Vajpayee gave the mission the go-ahead during his Independence Day address to the nation on 15 August. His speech was made as China prepares to steal a march on its Asian rival by sending a manned spacecraft into orbit this autumn.

The ISRO claims that the project has the

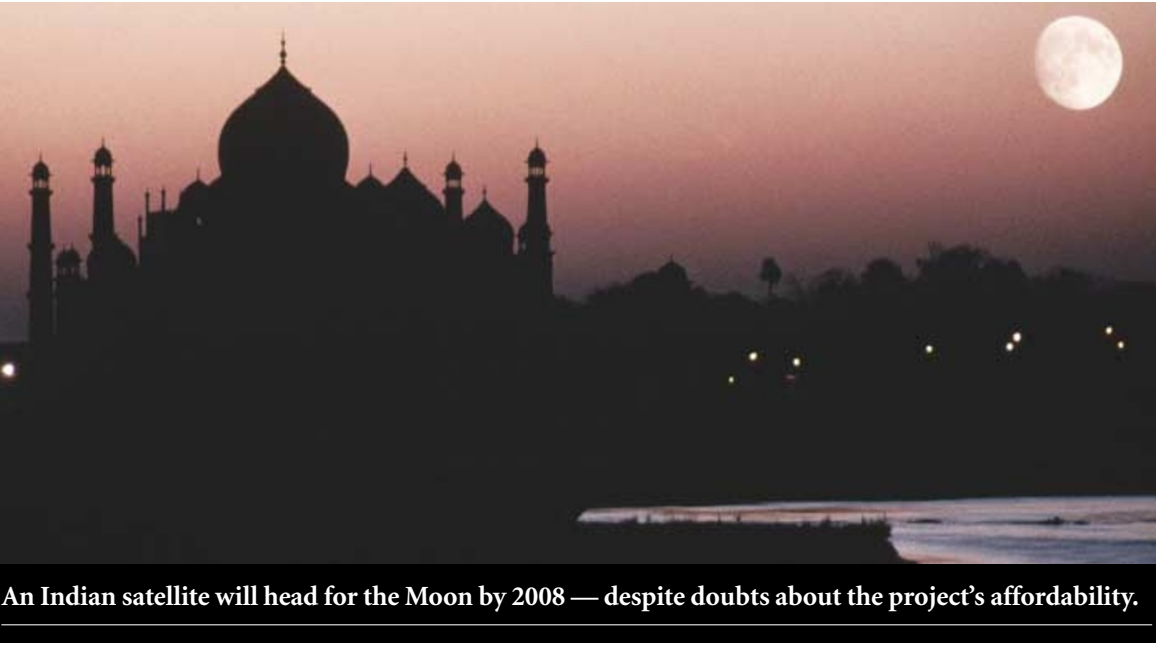

overwhelming support of India's scientific community. Jayant Narlikar, former director of the Inter-University Centre for Astronomy and Astrophysics at Pune, says that it offers an important "intellectual challenge" to the country and will result in technological spinoffs that will benefit society.

But not everyone agrees. D. Raghuraman, a physicist at the non-profit Delhi Science Forum, says that the mission is a "luxury India can hardly afford". And Roddam Narasimha, director of the National Institute of Advanced Studies in Bangalore, says that India would be better off doing lunar exploration as part of an international collaboration. He thinks that India should concentrate its attention on what is happening on Earth.

Chandrayan-1 will map the chemical composition of the entire lunar surface, and produce a three-dimensional atlas of regions of interest. In a statement, the ISRO said that the mission is a forerunner for other planetary missions, including "landing robots on the Moon and visits by Indian spacecraft to other planets in the Solar System". 